\title{
Neurofibromatosis Clinic: A Report on Patient Demographics and Evaluation of the Clinic
}

\author{
Alireza Mansouri, Saber Ghadakzadeh, Talha Maqbool, Carolina Barnett, \\ Karolyn Au, Paul Kongkham, Vera Bril, Gelareh Zadeh*
}

\begin{abstract}
Background: Neurofibromatosis type 1 (NF1) is a common single-gene disorder. A multidisciplinary approach to the management of NF1 patients is necessitated by the heterogeneity of clinical manifestations. Although multidisciplinary paediatric clinics have been well established, there is a dearth of such resources for adults with NF1. Herein we report our one-year institutional experience with a multidisciplinary adult NF1 clinic. Methods: A multidisciplinary team was assembled, and an NF Patient Registry Initiative questionnaire was adapted to collect patient-reported data during clinics. Multiple databases were searched to identify publications pertaining to the experience of other multidisciplinary NF1 clinics focusing on adult patients. Data on patient epidemiology and clinical staff were compared to our data. Results: A total of 77 patients were scheduled, and 68 attended the clinic, of whom 66 completed the intake questionnaire. The demographic and clinical data from this Canadian population are mostly consistent with previous reports, with some exceptions. Clinical data related to immune system involvement such as asthma, airway/breathing-related difficulties or allergies were striking in our NF1 population. Six relevant published reports of other NF1 clinics were identified. Reports from these studies pertained to periods ranging from 10 to 38 months, and the number of adults assessed ranged from 19 to 177 patients. Conclusions: The structure of our clinic and the patient volume are comparable to those of other established centres found in the literature. Our data offer valuable cross-sectional prevalence statistics in the Canadian population. The patient-reported data concerning involvement of the immune system contribute to an emerging recognized medical concern within the NF1 population and warrant further clinical and basic investigation.
\end{abstract}

RÉSUMÉ: Clinique de neurofibromatose : caractéristiques démographiques des patients et évaluation de la clinique. Contexte : La neurofibromatose de type 1 (NF1) est une maladie monogénique fréquente. Le traitement des patients atteints de NF1 nécessite une approche multidisciplinaire à cause de l'hétérogénéité des manifestations cliniques de la maladie. Bien que des cliniques pédiatriques multidisciplinaires soient bien établies, il existe un manque de ressources pour les adultes atteints de NF1. Nous rapportons notre expérience institutionnelle d'un an au sujet d'une clinique multidisciplinaire pour adultes atteints de NF1. Méthodologie : Nous avons créé une équipe multidisciplinaire et adapté le NF Patient Registry Initiative questionnaire afin que les patients le complètent lors des visites à la clinique. Nous avons interrogé plusieurs bases de données afin d'identifier des publications sur l'expérience d'autres cliniques multidisciplinaires pour adultes dédiées à la NF1. Nous avons comparé les données épidémiologiques concernant les patients et le personnel médical avec nos propres données. Résultats : Nous avions prévu la participation de 77 patients ; 68 se sont présentés à la clinique, dont 66 ont complété le questionnaire initial. Les données démographiques et cliniques de cette population canadienne concordent généralement avec les rapports précédents, à quelques exceptions près. Les données cliniques concernant l'implication du système immunitaire telles l'asthme, les difficultés respiratoires ou les allergies étaient importantes dans notre population NF1. Six publications pertinentes provenant d'autres cliniques NF1 ont été identifiées. Les rapports de ces études portaient sur des périodes variant de 10 à 38 mois et le nombre d'adultes évalués allait de 19 à 177 patients. Conclusions : La structure de notre clinique et notre volume de patients sont comparables à ceux d'autres centres dont l'expérience est rapportée dans la littérature. Nos données constituent des statistiques importantes sur la prévalence transversale de la NF1 dans la population canadienne. Les données rapportées par les patients concernant l'atteinte du système immunitaire soulignent une préoccupation médicale nouvellement reconnue dans la population de patients atteints de NF1 et mérite d'être examinée davantage tant au point de vue clinique que fondamental.

Keywords: Adult, clinic, neurofibromatosis, NF1, multidisciplinary

doi:10.1017/cjn.2016.326

Can J Neurol Sci. 2017; 44: 577-588

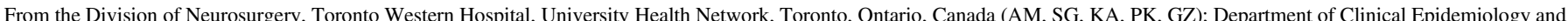

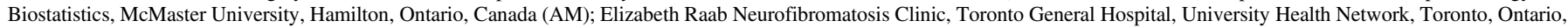

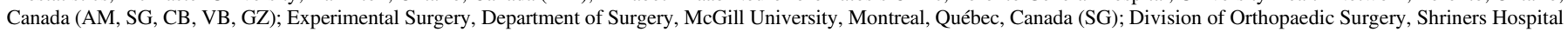

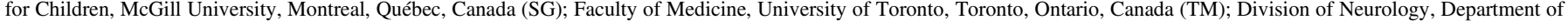
Medicine, University of Toronto, Toronto, Ontario, Canada (CB, VB).

*Gelareh Zadeh's name and initials have been corrected. A corrigendum notice detailing this change was also published (DOI: 10.1017/cjn.2017.250).

Received February 16, 2016. Date of Acceptance June 17, 2016.

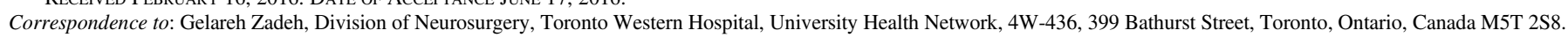
E-mail: Gelareh.Zadeh@uhn.ca. 


\section{INTRODUCTION}

Neurofibromatosis type 1 (NF1) (Mendelian Inheritance in Man [MIM] no. 162200]) is an autosomal dominant genetic disorder that occurs in approximately 1 in 2,500 to 3,000 individuals worldwide. ${ }^{1,2} \mathrm{NF} 1$ is caused by a mutation in the $N F 1$ gene, which normally encodes the tumour suppressor protein neurofibromin $(\mathrm{NF} 1)^{3}{ }^{3} \mathrm{NF} 1$ can be diagnosed either based on genetic testing or clinically. ${ }^{4}$ Patients with NF1 are at a higher predisposition for developing tumours of the nervous system, specifically along the peripheral nerves, along with cutaneous and skeletal abnormalities and learning disabilities. ${ }^{1,3,5,6}$ The spectrum of clinical manifestations in NF1 patients is diverse, even within members of an affected family. ${ }^{3}$ Consequently, optimal management is ideally provided through a multidisciplinary team (MDT), and hence the impetus for the establishment of comprehensive multidisciplinary clinics for patients with NF syndromes (NF1 and NF2).

The majority of multidisciplinary NF clinics have focused on the care of paediatric patients. ${ }^{7,8}$ The transition to adult care without a dedicated MDT adult NF clinic poses a significant clinical challenge. In particular, given that (similar to other rare and complex genetic disorders) our knowledge regarding the optimal management of NF1 is limited among both clinicians and affected patients, ${ }^{9}$ establishing MDTs focused on adult NF care is of paramount clinical value. There is currently a comparative dearth of comprehensive adult NF clinics, which ultimately leads to fragmented care of NF1 patients upon reaching adulthood. ${ }^{10}$ Though the biological consequences of NF1 are most prominently recognized and studied, the psychosocial aspects of this disorder cannot be understated. The underappreciated intellectual impact of NF1 results in significant disability, psychological suffering, decreased quality of life, limitation in societal integration and increased healthcare costs. $^{11-13}$ Thus, improving access to comprehensive multidisciplinary care for adults with NF1 can have numerous positive consequences for the patients, their caregivers, public health and, ultimately, society in general.

Although clinics providing care for adults have been established in various centres worldwide, ${ }^{10,14,15}$ no such clinic has existed in Canada, to the best of our knowledge. To address this gap in management, a collaborative effort between the divisions of neurosurgery and neurology began in January of 2014, enabling the establishment of the first adult NF (for both NF1 and NF2) clinic.

The objective of this report is to provide a one-year overview of the structure of our adult NF clinic, and of the volume of patients assessed, with a focus on their clinical and demographic characteristics. The current report pertains to our NF1 patients only. Data pertaining to NF2 patients are being evaluated separately, as their demographics and characteristics are going to vary considerably. The current achievements and limitations of our centre are discussed, and the goals for the future are outlined. In addition, we present an overview of other multidisciplinary NF centres providing care for adult patients, as identified through a review of the literature, to raise awareness of the essential role of such MDT clinics. In addition, we highlight the relevance and value of the intake questionnaire for tailoring the care of patients according to their specific needs and modifying the clinic structure to better serve those needs.

\section{Methods}

\section{Structure of Clinic}

The structure of the clinic is summarized in Table 1. The multidisciplinary team at the adult NF clinic is primarily comprised of two neurosurgeons with subspecialty interest in oncology and expertise in spinal and peripheral nerve pathology, two neurologists with subspecialty interest in peripheral neuropathy, a medical geneticist, a genetics counsellor and a nurse practitioner. A conference is held prior to each clinic to formulate a personalized approach for patients. A debriefing conference is also held upon conclusion of each clinic to ensure that a comprehensive management plan is formulated.

Both NF1 and NF2 patients are accepted in the clinic. Other affiliated specialists participate actively in the care of patients as indicated, including general surgery, plastics and orthopaedics, along with dedicated neuro-ophthalmology, endocrinology and dermatology for expediting necessary referrals. Referrals to our clinic are accepted from both family physicians and other specialists. At the outset, consultations were provided on a monthly full-day basis. This has gradually been increased, as awareness of the clinic has increased, to biweekly clinics. Patients suspected of suffering from NF-related peripheral neuropathy undergo nerve conduction studies/ electromyography, as necessary, during the course of the clinic visit.

In addition to the clinical staff, the clinic maintains close collaborations with local public organizations such as the Neurofibromatosis Society of Ontario (NFSO) and the Acoustic Neuroma Association of Canada (ANAC) for patient advocacy and dissemination of information.

\section{Intake Questionnaire}

All patients seen for the first time at the University Health Network (UHN) NF clinic are asked to complete a self-reported

\section{Table 1: Structure of UHN NF clinic}

\begin{tabular}{|c|c|}
\hline \multirow[t]{4}{*}{$\begin{array}{l}\text { Permanent } \\
\text { members }\end{array}$} & $\begin{array}{l}\text { Two neurosurgeons with subspecialty interest in oncology } \\
\text { along with expertise in spinal and peripheral nerve } \\
\text { pathology }\end{array}$ \\
\hline & $\begin{array}{l}\text { - Two neurologists with subspecialty interest in peripheral } \\
\text { neuropathy }\end{array}$ \\
\hline & - Medical geneticist* \\
\hline & - Genetics counsellor* \\
\hline \multirow[t]{6}{*}{ Affiliated members } & - General surgery \\
\hline & - Plastic surgery \\
\hline & - Orthopaedic surgery \\
\hline & - Neuro-ophthalmology \\
\hline & - Endocrinology \\
\hline & - Dermatology \\
\hline \multirow[t]{4}{*}{ Referral source } & - Adult and paediatric specialists \\
\hline & - Patient advocacy groups: \\
\hline & - Neurofibromatosis Society of Ontario (NFSO) \\
\hline & - Acoustic Neuroma Association of Canada (ANAC) \\
\hline \multirow[t]{2}{*}{ Clinic frequency } & - Initially full-day monthly clinic \\
\hline & - Currently half-day biweekly clinic \\
\hline
\end{tabular}

*Recent additions to team. 
intake questionnaire, including 114 data items, adapted from an NF Patient Registry Initiative project. ${ }^{16}$ All patients participating in the study were diagnosed with NF1 according to the diagnostic clinical characteristics defined by the National Institutes of Health (NIH) Consensus Conference. ${ }^{4}$ The patients signed an informed consent and completed a hard-copy of the NF1 questionnaire as part of their clinic visit. Clinic staff were made available to assist with completion of the questionnaire, given the length and details required to answer questions.

\section{Statistical Analysis}

Data were exported into IBM SPSS (v. 22.0, Chicago, Illinois, United States). Means and medians were compared using either the two-tailed $t$ test or the Mann-Whitney $U$ test. A value of $p<0.05$ was deemed significant.

\section{Literature Review}

\section{Databases Searched}

A review of the MEDLINE (1946 to April, Week 4, 2015), Embase (1947 to 2015, Week 18), and CENTRAL electronic databases was undertaken to identify publications pertaining to multidisciplinary clinics providing care for adults (age $\geq 18$ years) with NF1.

\section{Search Terms and Strategy}

The search was conducted using relevant MeSH and Emtree terms (developed separately for each database) (Appendix I). The identified abstracts were imported into EndNote x7.0, and duplicates were manually removed. The titles and abstracts were searched independently and in duplicate (AM and TM). To be eligible for inclusion, studies needed to describe an NF clinic, have a multidisciplinary healthcare team consisting of at least two dedicated specialists and have at least 10 adult patients in studies with mixed paediatric and adult populations. Conference abstracts, case reports/case series reporting on patients with NF who were not formally managed in a multidisciplinary setting, review articles and studies appearing in non-peer-reviewed journals were excluded.

Any discrepancies in inclusion were resolved through discussion. Cohen's kappa coefficient was employed to quantify the extent of agreement, with a value of 0.6-0.79 representing "substantial agreement" and a score of $0.80-1.0$ representing "almost perfect" agreement. ${ }^{17}$ This approach was utilized for the full-text search as well.

\section{Data Extraction}

One author (TM) extracted the following data from the selected full-text publications: country and city of clinic, year of establishment, patient population, types of specialists involved and main objectives of the publication. Data accuracy was confirmed independently by a second author (AM).

\section{Results}

\section{UHN NF Clinic Intake Questionnaire Responses \\ Patient Characteristics}

A total of 77 NF1 patients were scheduled to be seen in the UHN NF clinic over the course of a year, but 9 did not fulfill their appointment. Of the 68 patients who were seen, 66 (97\%) completed the self-reported intake questionnaire. All completed the questionnaires with assistance from family members and caregivers, if necessary. The demographic data from these patients are summarized in Table 2. The gender distribution of responding participants was approximately equal ( $44 \%$ male, $p=0.32$ ). The mean age of individuals was $32.6 \pm 11.8$ years $($ median $=29.5)$. The majority of patients $(42,64 \%)$ were older than 25 years. Only $6(9 \%)$ survey respondents had been referred directly from a paediatric centre, as transition to adult care. Some $44(67 \%)$ patients were single, $18(27 \%)$ married and $4(6 \%)$ divorced, and $1(2 \%)$ was living with a partner. The majority of our patients had a "European/Middle Eastern" background (51, 77\%), followed by "Asian" (9, 14\%) and "African American" (4, 6\%). Over $90 \%$ of total patients (60/66) were native English speakers, and the rest were fluent in English and did not have difficulty completing the questionnaire.

Table 2: Demographic data of 66 NF1 patients who completed the questionnaire

\begin{tabular}{|c|c|}
\hline Demographic information & $n(\%)$ \\
\hline \multicolumn{2}{|l|}{ Gender } \\
\hline Male & $29(44)$ \\
\hline Female & $37(66)$ \\
\hline \multicolumn{2}{|l|}{ Age (years) } \\
\hline 18 & $6(9)$ \\
\hline $19-25$ & $18(27)$ \\
\hline$>26$ & $42(64)$ \\
\hline \multicolumn{2}{|l|}{ Marital status } \\
\hline Single & $43(65)$ \\
\hline Married & $18(27)$ \\
\hline Divorced & $3(5)$ \\
\hline Living with a partner & $2(3)$ \\
\hline \multicolumn{2}{|l|}{ Highest level of education } \\
\hline Graduate school (masters level) & $4(6)$ \\
\hline University (undergraduate) & $14(21)$ \\
\hline College & $20(30)$ \\
\hline High school & $21(32)$ \\
\hline Elementary & $3(5)$ \\
\hline No formal education & $1(2)$ \\
\hline Not known & $3(4)$ \\
\hline \multicolumn{2}{|l|}{ Racial background } \\
\hline White & $51(77)$ \\
\hline Black/African American & $4(6)$ \\
\hline Asian & $9(14)$ \\
\hline Other $^{1}$ & $2(3)$ \\
\hline \multicolumn{2}{|l|}{ Native language } \\
\hline English & $60(91)$ \\
\hline Other & $6(9)$ \\
\hline
\end{tabular}

${ }^{1}$ Other racial backgrounds: "Hispanic or Latino," "American Indian or Alaskan Native" or "Native Hawaiian/Other Pacific Islander." 


\section{Genetic Screening and Family History}

A total of $26(39 \%)$ participants reported that they had had a genetic testing, 20 (77\%) of whom had an NF1 mutation, while in $2(8 \%)$ the mutation was not detected; the remaining $4(15 \%)$ patients were not aware of the results of their tests, which were performed previously in a different country. However, the clinical diagnosis of NF1 was established in all participants according to the diagnostic clinical characteristics defined by the NIH Consensus Conference. ${ }^{4}$

In $28(43 \%)$ participants, the inheritance pattern of NF1 was familial, and there was at least one first-degree family member afflicted with NF1 (parent of origin: 50\% maternal, 50\% paternal). Another $28(43 \%)$ patients were sporadic (no other family members with NF1). The remaining 10 patients were not aware of an NF1 diagnosis among their first-degree relatives (living or deceased). None of the patients were the result of a twin (or higher) pregnancy.

\section{Educational Status}

Among all respondents, $25(38 \%)$ had undergone an individualized education program (IEP). Only 18 (27\%) were enrolled in or had graduated from a university program, 20 (30\%) had a college diploma (or were currently in college), 21 (32\%) had completed high school, and the remaining 27 (48\%) had not finished high school. Among the 54 participants attending some form of educational program, $8(15 \%)$ had to repeat at least one grade (any of grades 1 to 11 ).

\section{Associated Disorders Affecting Function}

Occupational therapy and physical therapy support were sought in only $2(3 \%)$ and $4(6 \%)$ patients, respectively. Six participants $(9 \%)$ were diagnosed with a hearing deficit, $13(20 \%)$ with a speech impediment, $18(27 \%)$ with a learning disability, $3(5 \%)$ with mental retardation, $20(30 \%)$ with anxiety, $13(20 \%)$ with ADHD, 12 (18\%) with depression and $3(5 \%)$ with an eating disorder. Those who were ever engaged in self-mutilation accounted for $5 \%$ of the studied population, and another $5 \%$ attempted leaving home permanently at least once; $5 \%$ attempted suicide, and $3 \%$ suffered from substance abuse. Only 8 patients $(12 \%)$ knew someone other than a family member with NF1, 55 patients $(83 \%)$ stated that they did not know anyone else with $\mathrm{NF} 1$, and $3(5 \%)$ did not provide an answer for this field.

\section{Concurrent Clinical Manifestations}

The data pertaining to clinical manifestations are summarized in Table 3. The majority of patients exhibited $\geq 6$ café-au-lait macules and $>2$ freckles in the axilla/groin, as reported by $58(88 \%)$ and $44(67 \%)$ of participants, respectively; $21 \%$ of our patients (14/66) were not aware of the presence of freckles in the specified body areas. Lisch nodules had been diagnosed in $22(33 \%)$ patients, while $23(35 \%)$ were not certain. Among all orthopaedic manifestations, scoliosis had the highest rate (25 patients, 38\%). Migraine headaches were experienced by $19(29 \%)$ participants.

\section{Tumour/Cancer History}

Tumour types, along with their pertinent management approach (reported by patients), are summarized in Table 3. Brain tumours were diagnosed in $13(20 \%)$ patients. In approximately
$40 \%$ of these patients, the tumours were treated by surgery; $8 \%$ received chemotherapy, $16 \%$ radiation therapy or Gamma Knife surgery; $23 \%$ were under observation; and the rest were not sure about their treatments. Plexiform neurofibroma history was present in $21(32 \%)$, absent in $25(38 \%)$ and unknown in $20(30 \%)$ patients. Among those with this tumour, $17(81 \%)$ were managed surgically, 1 (5\%) was being managed conservatively with observation, and the remaining $3(14 \%)$ patients were not certain about their treatment. Only 1 patient $(2 \%)$ had a history of malignant peripheral nerve sheath tumour (MPNST), which was managed surgically. Additionally, 11 (17\%) participants were diagnosed with other tumours, including a spinal neurofibroma, lymphoma (2\%), lung cancer ( $2 \%)$, neuroblastoma $(2 \%)$ and other tumours/cancers (2\%). The majority of patients $(58 \%)$ had blood relatives diagnosed with colon cancer $(21 \%)$, breast cancer (20\%), brain tumours (12\%), melanoma and lymphoma (each $9 \%)$, leukemia $(6 \%)$ or other types of cancer not listed above (14\%).

\section{Immune System Involvement}

Involvement of the immune system in NF1 patients has been postulated in a few previous clinical studies. ${ }^{18-20}$ Over $27 \%$ of patients were informed by a health professional that they had asthma. Some $14 \%$ of patients had suffered from airway/ breathing-related difficulties requiring a visit to the emergency department. A diagnosis of allergy had been made in $36 \%$ of respondents. Approximately $20 \%$ stated that they had hives, and $29 \%$ had eczema in the past, $68 \%$ of whom did not have a family history of eczema among immediate family members.

\section{Literature Review of Other Adult NF Center Experiences}

\section{Search Results}

Our search of the MEDLINE (191 results), Embase (118 results) and CENTRAL (1 result) databases yielded a total of 310 results. An additional five abstracts were identified through a manual screen of relevant references. Screening of titles/abstracts yielded 13 studies for full-text review, 6 of which were identified as relevant to our search focus. The interrater agreement for the title/abstract and full-text screening was "almost perfect," with kappa scores of $0.82\left(C_{95 \%}=0.66-0.97\right)$ and $0.84 \quad\left(C I_{95 \%}=0.55-1.0\right)$, respectively. Please refer to Figure 1 for the PRISMA flow diagram summarizing our search results.

Among the 13 selected articles for full-text review, one was translated from Portuguese (Brazilian), and 7 studies were excluded following full-text review. ${ }^{10,15,21-25}$ For a summary of included studies and the rationale for the excluded studies, please refer to Table 4.

\section{Characteristics of Included Studies}

While only one study pertained to strictly adult patients, ${ }^{26}$ the remaining five applied to the management of both adult and paediatric patients. ${ }^{27-31}$ Two centres were based in the United States (Boston and St. Louis), ${ }^{26,27}$ two were based in Australia (Melbourne and Camperdown), ${ }^{28,29}$ one was based in Brazil (Rio de Janeiro $)^{30}$ and one was based in France (Crédeil). ${ }^{31}$ No Canadian centres were identified in our database search. The date of establishment was not readily available in all original 
Table 3: Associated clinical manifestations

\begin{tabular}{|c|c|c|c|c|c|c|c|c|}
\hline Associated condition & $\begin{array}{c}\text { Present/ } \\
\text { diagnosed, } \\
n(\%)\end{array}$ & $\begin{array}{c}\text { Not present/ } \\
\text { not diagnosed, } \\
n(\%)\end{array}$ & $\begin{array}{l}\text { Not known, } \\
\quad n(\%)\end{array}$ & & & & & \\
\hline \multicolumn{9}{|l|}{ Dermatologic } \\
\hline - 6 or more café-au-lait spots & $58 / 66(88)$ & $4 / 66(6)$ & $4 / 66(6)$ & & & & & \\
\hline $\begin{array}{l}\text { More than two freckles in the axilla } \\
\text { and/or }>2 \text { freckles in the groin }\end{array}$ & $44 / 65(67)$ & $8 / 65(12)$ & $13 / 65(21)$ & & & & & \\
\hline \multicolumn{9}{|l|}{ Ophthalmologic } \\
\hline - Lisch nodules & $22 / 66(33)$ & $21 / 66(32)$ & $23 / 66(35)$ & & & & & \\
\hline \multicolumn{9}{|l|}{ Orthopaedic } \\
\hline - Forearm bowing & $1 / 66(2)$ & $43 / 66(65)$ & $22 / 66(33)$ & & & & & \\
\hline - Lower leg bowing & $5 / 66(8)$ & $36 / 66(54)$ & $25 / 66(38)$ & & & & & \\
\hline - Both & $1 / 66(2)$ & $40 / 66(62)$ & $25 / 66(38)$ & & & & & \\
\hline - Scoliosis & $25 / 66(38)$ & $27 / 66(41)$ & $14 / 66(21)$ & & & & & \\
\hline \multicolumn{9}{|l|}{ Cardiovascular } \\
\hline - Hypertension & $5 / 66(8)$ & $60 / 66(90)$ & $1 / 66(2)$ & & & & & \\
\hline - Heart murmur & $5 / 66(8)$ & $60 / 66(90)$ & $1 / 66(2)$ & & & & & \\
\hline \multicolumn{9}{|l|}{ Neurological } \\
\hline - Seizures or epilepsy & $11 / 66(17)$ & $54 / 66(81)$ & $1 / 66(2)$ & & & & & \\
\hline \multirow[t]{2}{*}{ - Migraine headaches } & $19 / 66(29)$ & $46 / 66(69)$ & $1 / 66(2)$ & & & & & \\
\hline & & & & \multicolumn{5}{|c|}{ Management of oncological conditions } \\
\hline Oncologic & & & & Surgery & Observation & Chemotherapy & Radiation & $\begin{array}{c}\text { Not } \\
\text { known }\end{array}$ \\
\hline - Brain tumour & $13 / 66(20 \%)$ & $47 / 66(71 \%)$ & $6 / 66(9 \%)$ & $5 / 13(40 \%)$ & $3 / 13(23 \%)$ & $1 / 13(8 \%)^{*}$ & $2 / 13(16 \%)$ & $2 / 13(16 \%)$ \\
\hline - Plexiform tumour & $21 / 66(32 \%)$ & $25 / 66(38 \%)$ & $20 / 66(30 \%)$ & $17 / 21(81 \%)$ & $1 / 21(5 \%)$ & - & - & $3 / 21(14 \%)$ \\
\hline - MPNST & $1 / 66(2 \%)$ & $51 / 66(77 \%)$ & $14 / 66(21 \%)$ & $1 / 1(100 \%)$ & - & - & - & - \\
\hline - Other tumours/cancers** & $9 / 66(14 \%)$ & $55 / 66(83 \%)$ & $2 / 66(3 \%)$ & - & - & - & - & - \\
\hline
\end{tabular}

*This patient received chemotherapy in combination with surgery and radiation therapy.

**Spine tumours (6), lymphoma (1), leiomyosarcoma (1), neuroblastoma (1).

publications, and a supplemental online search was necessary in some cases. The earliest established centre was in Boston (1982), ${ }^{26}$ while the most recent centre was based on a report from the NF clinic at the Royal Children's Hospital in Melbourne, which was established in 2001 primarily for paediatric patients, but it also provided services for adult family members. ${ }^{28}$ The period reported in these studies ranged from 10 to 38 months. The number of adult patients seen in these clinics ranged from 19 to 177. The gender distribution demonstrated a pattern correlating with the proportion of adult and paediatric patients enrolled. Among studies with a higher proportion of adults, the ratio of female patients was higher than males (1.36-1.5:1). Among the four reports with a clearly defined medical structure, neurologists and geneticists were present in all; the patient population was mixed in all of these clinics. ${ }^{27-30}$ None of the identified clinics with published reports had a permanent neurosurgical presence.

Three publications reported on the frequency of clinics, ${ }^{27-29}$ ranging from twice a week to monthly. The inability to coordinate the schedules of various specialists involved was quoted as the reason for not holding clinics more frequently. ${ }^{27}$ Three centres accepted referrals from national/local NF organizations. $^{27,29,31}$

\section{DisCUSSION}

Herein we have reported on the evolving design and structure of the UHN NF clinic in Toronto, Canada. Our structure has been compared with six other centres with published reports on the structure and outcome of their clinics, to identify areas of potential improvement. In addition to being a dedicated multidisciplinary NF clinic for adults in Canada, the Toronto NF clinic is also a pioneer in Ontario in involving the permanent presence of the neurosurgical specialty. Having neurosurgeons as permanent members in the clinic helped to streamline the process for surgical interventions. Furthermore, this report also serves as a crosssectional prevalence profile of the status of adults with NF1 in Canada. The patient-reported data described in this report delineate the clinical heterogeneity of NF1 individuals in terms of their complications and manifestations, thus offering valuable information to healthcare providers and families dealing with this condition, particularly in Canada. Given the wide-ranging patientlevel and societal impact of this chronic disorder, there is a need to study different populations to obtain accurate disease statistics, to establish additional multidisciplinary NF clinics and to strengthen community links with existing ones. 
PRISMA 2009 Flow Diagram

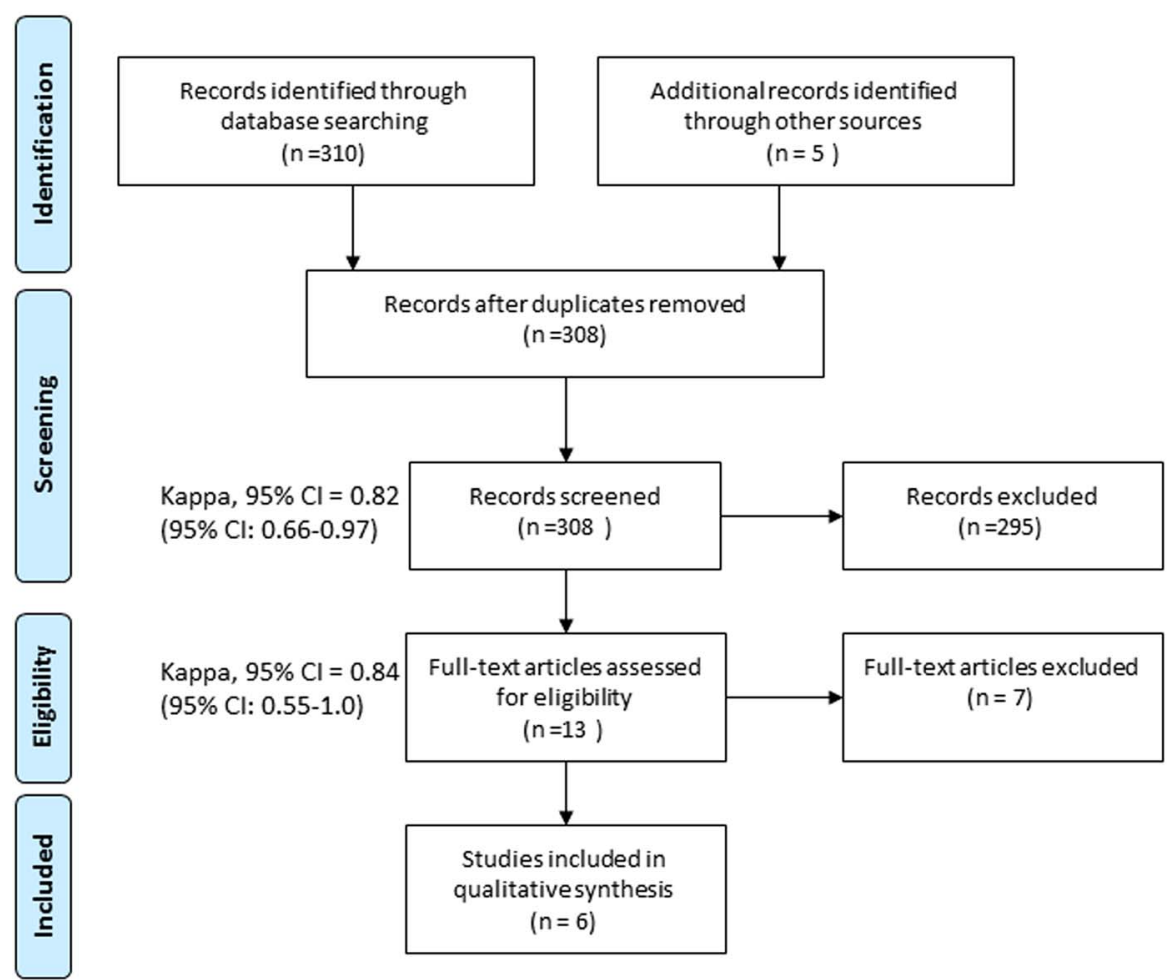

Figure 1: PRISMA flow diagram summarizing our search results.

\section{Clinic Structure, Patient Demographics and Key Diagnostic Features}

Initially, we had sought to conduct monthly full-day clinics. However, given the need for conducting a thorough set of comprehensive assessments, we determined that this structure would be detrimental to the quality of care. Thus, the setup was changed to biweekly half-day clinics, involving a smaller number of patients, allowing for extended assessments as necessary. Only $9 \%$ of our patients were referred directly from the paediatric NF services at the Hospital for Sick Children in Toronto, highlighting the need to increase awareness of the newly established adult NF clinic and the importance of establishing a streamlined referral process for patients transitioning from paediatric to adult care.

The gender distribution in our study was approximately equal. Although the gender distribution has generally been thought to be equal in NF1, most of the adult-specific studies identified in our review have reported a higher proportion of females. ${ }^{28-31}$

The frequency of patients with café-au-lait spots and freckling in our adult cohort was similar to other reports, increasing the confidence in the clinical diagnosis of our patient cohort. ${ }^{24}$ Lisch nodules, however, were reported less frequently than the average population frequency. ${ }^{24}$ While a dedicated neuro-ophthalmologist is affiliated with our clinic, the results presented here pertain to the intake visit data only and reflect the potentially incorrect prior diagnoses (due to fragmented care) or limited patient understanding regarding this manifestation. ${ }^{32,33}$

\section{Genetic Screening and Family History}

A total of 42 patients $(61 \%)$ had been diagnosed clinically and had not had prior genetic testing. A familial inheritance pattern was reported in $43 \%$ of our patients. The complexity of the disorder and the high number of unique genetic mutations identified to date in NF1 patients warrants a structured and comprehensive approach toward genetic analysis and counselling. ${ }^{34}$ Establishing the extent of the patient/family understanding of the disorder and recruiting them as partners in their care is a necessary first step. $^{35}$ Couples counselling and discussions regarding reproductive strategies are likely to be key components of the counselling requirements. While various reproductive options are available, the moral and ethical factors associated with these must be considered as well. ${ }^{35}$ With the accumulation of increasing knowledge regarding the genetics of this disorder, the opportunities for personalized medicine are expanding. Given the lack of uniform genetic testing, the low percentage $(29 \%)$ of our patients on intake being aware of their genetic status and its implications for family planning, the need to integrate a dedicated genetics team (medical geneticist and genetics counsellor) was identified and initiated as a result of the questionnaire results.

\section{Educational Status}

Learning disability was only reported by $27 \%$ of patients. While this is lower than in some studies, with rates as high as $62 \%$ reported, ${ }^{24}$ the difficulty with defining the various types of learning disabilities and ascertainment of patient responses in the absence of a formal neuropsychological assessment limits the reliability of this value for our study.

According to the 2011 National Household Survey (NHS) in Canada, almost two-thirds of adult Canadians had postsecondary qualifications. In our patient population, $57 \%$ had or were in the process of acquiring a postsecondary degree, which is roughly 


\section{Table 4: Summary of study characteristics for included publications and rationale for study exclusion}

\begin{tabular}{|c|c|c|c|c|c|c|c|}
\hline $\begin{array}{l}\text { First author } \\
\text { (year of } \\
\text { publication) }\end{array}$ & Country, city & Name of centre & Year established & $\begin{array}{l}\text { Time period report } \\
\text { pertains to }\end{array}$ & $\begin{array}{l}\text { Population type/number of } \\
\text { adults vs. paediatric/overall } \\
\text { male:female ratio }\end{array}$ & $\begin{array}{l}\text { Permanent/affiliated medical } \\
\text { members }\end{array}$ & Main objectives \\
\hline Wang $(2012)^{26}$ & USA, Boston & $\begin{array}{l}\text { The Family Center } \\
\text { for NF at } \\
\text { Massachusetts } \\
\text { General } \\
\text { Hospital } \\
\end{array}$ & $1982^{\# \#}$ & $\begin{array}{l}10 \text { months (January to } \\
\text { November of 2010) }\end{array}$ & $\begin{array}{l}\text { Strictly adults (all NF } \\
\text { syndromes)/133/54:79 }\end{array}$ & $\begin{array}{l}\text { Neurology } \\
\text { Psychiatry }\end{array}$ & $\begin{array}{l}\text { To assess emotional status } \\
\text { among adults with NF }\end{array}$ \\
\hline $\operatorname{Beckman}(1988)^{27}$ & USA, St. Louis & $\begin{array}{l}\text { Cardinal Glennon } \\
\text { Children's } \\
\text { Hospital NF } \\
\text { clinic }\end{array}$ & $1984^{\wedge}$ & 30 months & $\begin{array}{l}\text { Mix of adults and paediatrics/ } \\
\sim 37^{\mathbb{I I} / N / A}\end{array}$ & $\begin{array}{l}\text { Permanent: neurology, } \\
\text { orthopaedics, genetics, } \\
\text { ophthalmology, paediatrics, } \\
\text { and nurse coordinator } \\
\text { Affiliated: plastic surgeon, } \\
\text { neurosurgeon, general } \\
\text { surgeon, paediatric surgeon, } \\
\text { dermatologist, } \\
\text { otolaryngologist, audiologist }\end{array}$ & $\begin{array}{l}\text { To share initial experiences } \\
\text { with establishing the } \\
\text { multidisciplinary NF clinic } \\
\text { such that future centres can } \\
\text { be established more } \\
\text { efficiently and effectively }\end{array}$ \\
\hline Noble $(2007)^{28}$ & $\begin{array}{l}\text { Australia, } \\
\text { Melbourne }\end{array}$ & $\begin{array}{l}\text { NF clinic at the } \\
\text { Royal } \\
\text { Children's } \\
\text { Hospital in } \\
\text { Melbourne }\end{array}$ & 2001 & $\begin{array}{l}38 \text { months (March } 2001 \text { to May } \\
\text { 2004) }\end{array}$ & $\begin{array}{l}\text { Mix of adults and paediatrics/ } \\
\text { 19/62:59 }\end{array}$ & $\begin{array}{l}\text { Permanent: clinical geneticist, } \\
\text { paediatric neurologist, } \\
\text { paediatric ophthalmologist } \\
\text { Affiliated: clinical } \\
\text { neuropsychologist, an } \\
\text { endocrinologist, oncologist, } \\
\text { nephrologist and plastic } \\
\text { surgeon }\end{array}$ & $\begin{array}{l}\text { To report on type and frequency } \\
\text { of NF1-related } \\
\text { complications in cohort of } \\
\text { NF1 patients seen at clinic }\end{array}$ \\
\hline North $(1993)^{29}$ & $\begin{array}{l}\text { Australia, } \\
\text { Camperdown }\end{array}$ & $\begin{array}{l}\text { NF clinic at the } \\
\text { Children's } \\
\text { Hospital in } \\
\text { Camperdown }\end{array}$ & 1991 & $\begin{array}{l}18 \text { months (March } 1991 \text { to } \\
\text { September 1992) }\end{array}$ & $\begin{array}{l}\text { Mix of adults and paediatrics/ } \\
74^{\wedge} / 94: 106\end{array}$ & $\begin{array}{l}\text { Permanent: neurologist and } \\
\text { medical geneticist } \\
\text { Affiliated: ophthalmologist }\end{array}$ & $\begin{array}{l}\text { To describe the clinical } \\
\text { characteristics of the first } 200 \\
\text { patients seen in the NF clinic }\end{array}$ \\
\hline $\begin{array}{l}\text { Trovó-Marqui } \\
(2005)^{30}\end{array}$ & $\begin{array}{l}\text { Brazil, Rio de } \\
\quad \text { Janeiro }\end{array}$ & $\begin{array}{l}\text { Center of Research } \\
\text { and Service in } \\
\mathrm{NF}\end{array}$ & N/A & $\begin{array}{l}24 \text { months (June } 2001 \text { to June } \\
\text { 2003) }\end{array}$ & $\begin{array}{l}\text { Mix of paediatrics and adults/ } \\
44 \text { vs. } 11 / 22: 33\end{array}$ & $\begin{array}{l}\text { Geneticists, ophthalmologists, } \\
\text { dermatologists, neurologists, } \\
\text { radiologists, gynaecologists, } \\
\text { cardiologists, } \\
\text { otorhinolaryngologists, } \\
\text { pathologists, orthopaedists } \\
\text { and psychologists }\end{array}$ & $\begin{array}{l}\text { To evaluate clinical features of } \\
\text { Brazilian patients with NF1 } \\
\text { referred to centre }\end{array}$ \\
\hline $\begin{array}{l}\text { Wolkenstein } \\
\qquad(2000)^{31}\end{array}$ & France, Crédeil & Reseau NF & N/A & $\begin{array}{l}17 \text { months (June } 1995 \text { to } \\
\text { November 1996) }\end{array}$ & $\begin{array}{l}\text { Mix of adults and paediatrics*/ } \\
177 \mathrm{vs} / 85: 116^{* *}\end{array}$ & Not clearly stated & $\begin{array}{l}\text { To assess medical needs and } \\
\text { evaluate costs of these needs } \\
\text { for NF1 patients }\end{array}$ \\
\hline
\end{tabular}


Table 4: (Continued)

\begin{tabular}{|c|c|c|c|c|c|c|c|}
\hline $\begin{array}{l}\text { First author } \\
\text { (year of } \\
\text { publication) }\end{array}$ & Country, city & Name of centre & Year established & $\begin{array}{l}\text { Time period report } \\
\text { pertains to }\end{array}$ & $\begin{array}{l}\text { Population type/number of } \\
\text { adults vs. paediatric/overall } \\
\text { male:female ratio }\end{array}$ & $\begin{array}{l}\text { Permanent/affiliated medical } \\
\text { members }\end{array}$ & Main objectives \\
\hline \multicolumn{8}{|l|}{ Excluded studies } \\
\hline \multirow[t]{3}{*}{ Oates $(2013)^{10}$} & \multicolumn{4}{|c|}{ Follow-up survey of patients seen in paediatric clinic } & \multicolumn{3}{|c|}{ - Assessment of burden of NF1 disease in young adults } \\
\hline & & & & & \multicolumn{3}{|c|}{ - Assessment of knowledge regarding disease in young adults with NF1 } \\
\hline & & & & & \multicolumn{3}{|c|}{ - Assessment of available national (Australian) surveillance strategy for young adults with NF1 } \\
\hline \multirow[t]{3}{*}{ Duong $(2011)^{15}$} & \multicolumn{4}{|c|}{$\begin{array}{l}\text { Retrospective assessment of mortality rate among NF1 patients as identified by disease identifier, } \\
\text { rather than assessed in a multidisciplinary clinic }\end{array}$} & \multicolumn{3}{|c|}{$\begin{array}{l}\text { - Standardized mortality ratio was significantly higher in NF1 patients (SMR 2.02), primarily in patient } \\
\text { age groups 10-20 years (SMR 5.2) and 20-40 years (SMR 4.1) }\end{array}$} \\
\hline & & & & & \multicolumn{3}{|c|}{ - Females had a significantly higher mortality rate than males (SMR 12.6) } \\
\hline & & & & & \multicolumn{3}{|c|}{$\begin{array}{l}\text { - Death due to malignant peripheral nerve sheath tumour was the major cause ( } 60 \% \text { of } 58 \text { patients with } \\
\text { available mortality data) }\end{array}$} \\
\hline $\begin{array}{l}\text { Bonalumi Filho } \\
(2010)^{21}\end{array}$ & \multicolumn{4}{|c|}{ The proportion of adult and paediatric patients not clear } & \multicolumn{3}{|c|}{ - Assessment of the epidemiology of NF1 at a local clinic in Rio de Janeiro } \\
\hline Duong $(2011)^{22}$ & \multicolumn{4}{|c|}{ Dermatological assessment of adults with NF1 } & \multicolumn{3}{|c|}{ - To report the evolution of cutaneous lesions during adulthood } \\
\hline Orion $(2012)^{23}$ & \multicolumn{4}{|c|}{$\begin{array}{l}\text { "Psychodermatology clinic" whereby multidisciplinary care is provided by a dermatologist with } \\
\text { training in psychotherapy and a medical psychologist; however, only one patient with NF1 was } \\
\text { seen }\end{array}$} & \multicolumn{3}{|c|}{$\begin{array}{l}\text { - To present the concept of a "psychodermatology" multidisciplinary clinic, outline its advantages } \\
\text { along with difficulties encountered, and to provide preliminary results }\end{array}$} \\
\hline $\begin{array}{l}\text { McGaughran } \\
(1999)^{24}\end{array}$ & \multicolumn{4}{|c|}{$\begin{array}{l}\text { A clinical study based on NF1 patients identified through a regional genetic registry rather than a } \\
\text { dedicated multidisciplinary clinic }\end{array}$} & \multicolumn{3}{|c|}{ - To present the features and complications associated with NF1 } \\
\hline Zoller $(1995)^{25}$ & \multicolumn{4}{|c|}{ A long-term follow-up epidemiological study of NF1 patients in Göteborg, Sweden } & \multicolumn{3}{|c|}{$\begin{array}{l}\text { - To determine long-term life expectancy and mortality rates in NF1 patients along with identifying } \\
\text { factors predictive of mortality (hypertension and malignancy) }\end{array}$} \\
\hline
\end{tabular}

\#\#Information not provided in paper but rather obtained from http://www.massgeneral.org/neurology/services/treatmentprograms.aspx?id=1357.

${ }^{¥}$ Ascertained based on departmental affiliation of authors.

Anformation not provided in paper but rather obtained from http://www.cardinalglennon.com/medicalspecialties/neurofibromatosis/Pages/Neurofibromatosis.aspx.

${ }^{\wedge}$ This value pertains to the number of individuals older than 20 ; exact number of adults $>18$ not provided.

${ }^{\text {IT }}$ The authors reported that $>150$ patients were seen (exact value not provided) and that $75 \%$ of these were children (definition not provided)

*Adults were defined as 16 years of age or older (24 patients were younger than 16).

**Among the 201 patients, only 137 were considered as having required "multidisciplinary" care (defined as three or more specialists involved).

Abbreviations: $\mathrm{NF}=$ neurofibromatosis, $\mathrm{SMR}=$ standardized mortality ratio. 
$10 \%$ below the national Canadian average. Additionally, $7 \%$ of patients had either no formal education or just elementary-level education, and $15 \%$ repeated at least one grade. Moreover, roughly $40 \%$ of individuals had received an IEP, emphasizing the learning and educational complications in this population. Particular learning issues have been reported in $30-45 \%$ of NF1 children. $^{29,36-38}$ Several NF1-related factors-such as ADHD, speech impediment, anxiety and depression-could account for such learning issues and educational decline in the affected individuals. These data stress the need to include learning assessment diagnostic tools in the routine clinical management of NF1 patients and, most importantly, early on in the education process. Moreover, families should be educated about such learning difficulties and encouraged to consider IEPs for their affected children. Furthermore, the creation and extension of links between community learning centres and an MDT would be critical for ongoing feedback with respect to gains accomplished in this regard. Currently, our centre is focused on raising government and private funds to establish such links.

\section{Associated Disorders Affecting Function}

A substantial proportion of patients in our study suffered from self-reported depression and anxiety. Although these were not formally confirmed, previous publications utilizing formal neuropsychological tools have confirmed the statistically higher prevalence of these mood disorders in NF1 patients compared with the general population. ${ }^{26}$ ADHD was reported to have been diagnosed at some point in $18 \%$ of our adult patients. The incidence of ADHD in children with NF1 has been quoted to be as high as $54 \%,{ }^{39}$ and while evidence suggests that some patients continue with symptoms of inattentiveness into adulthood, very little prevalence data exist for the adult NF1 population. Together, these findings highlight the essential need for neuropsychological and psychiatric support. As a consequence, the need for establishing relationships with neuropsychiatry and social work has been highlighted by this questionnaire and has provided the basis for pursuing institutional support for the NF population.

\section{Tumour/Cancer History}

The diagnosis of brain tumours was reported in $20 \%$ of our NF1 patients, which is consistent with previous reports. The most common intracranial tumours in NF1 are the visual pathway gliomas, with an incidence of 10-20\%, mostly emerging during the first 10 years of life. ${ }^{40-42}$

A positive history of plexiform neurofibromas was present in $32 \%$ of our population. Plexiform neurofibromas have been reported in nearly half of NF1 patients. ${ }^{43-45}$ As the data about this tumour are not available for $30 \%$ of our respondents, it is difficult to comment on the data derived from our population or extrapolate the data from previous studies to our work. Nevertheless, one of the main limitations in clinical diagnosis of plexiform neurofibroma is partly due to its heterogeneity and sometimes asymptomatic nature. ${ }^{44,46}$ This suggests the necessity for meticulous image analysis of patients through MR imaging, especially those with relevant pain complaints for prompt diagnosis. ${ }^{47-49}$ At our clinic, we perform imaging and clinical follow-up on patients with plexiform neurofibromas every six months, unless there are any concerning clinical features.
Among all the participants in our study, one individual reported a previous diagnosis of MPNST, which was higher than the reported prevalence rate of $0.1 \%$ in NF1 patients. ${ }^{32,50,51}$ The cumulative lifetime risk of MPNST in NF1 patients has been estimated to be about $8-13 \%$, with many patients developing this malignant tumour at around 30 years of age. ${ }^{52-54}$ Although $21 \%$ of participants were not certain with regard to a prior diagnosis of MPNST, more than $50 \%$ of our patients were younger than 30 . Therefore, these patients require close clinical and radiological surveillance for this malignant tumour as they approach the age of 30. Having dedicated neuro-oncology surgeons and neurologists as the mainstay of our clinic has been an invaluable model.

\section{Immune System Involvement}

In our population, the responses to the "immune system" questions were striking: more than $27 \%$ (18/66) reported that they had asthma and over $35 \%$ stated that they had experienced at least one asthma-related symptom. According to the Ontario Asthma Surveillance Information System (OASIS), the cumulative prevalence of asthma in Ontario in 2009 was approximately $10 \%$, along with an incidence of $\sim 5$ (per 1000 population), ${ }^{55}$ which is far less than what has been reported in our NF1 patients. Only a small number of groups have documented immune system involvement in NF populations previously. In a case-control study in Japan, 47\% of 227 NF1 patients suffered from such allergic diseases as bronchial asthma, allergic rhinitis or atopic dermatitis. ${ }^{56}$ A previous study has also shown elevated serum immunoglobulin E (IgE) levels in samples derived from NF1 patients. $^{20,57}$ Several studies have indicated the increase in mast cells (and other T-cell subsets) and their infiltration in NF1 neurofibromas, both in human NF1 samples ${ }^{58-62}$ and also in genetically engineered animal models of NF1. ${ }^{63-65}$ This is intriguing, as mast cells are the key sources of histamines, ${ }^{66}$ playing a crucial role in airway hyper-responsiveness and the pathogenesis of bronchial asthma. Interestingly, there are reports showing the positive effects of histamine stabilizers (e.g., ketotifen) on both pruritus and on the growth of neurofibromas in NF1 patients, ${ }^{67}$ suggesting a role for a dysregulated immune system in NF1 and a potential explanation for the reported immune-related complications in our population. The molecular cascade of autoimmune disorders and their association with NF1 warrants further attention and in-depth research. This is an evolving area, gaining more recognition as an associated medical condition and one that would benefit from further dedicated clinical care and research investigation. Through collaboration with geneticists and immunologists, this is an area we seek to address in the future.

\section{STUdy Limitations}

Although the identification of other published adult NF1 clinic experiences was performed through an extensive review, not all relevant reports are necessarily identified and indexed as per our search criteria. Additionally, not all groups have published on the structure and outcomes of their established NF clinics, and, as such, there are likely multidisciplinary NF clinics in different centres that were not included in our review as there is no report of them in the literature. Nonetheless, a diverse set of clinical experiences from a range of geographical regions and sample sizes was identified. 
While this study adds a unique information set to the small but growing literature on the NF1 population, some substantial limitations exist. First of all, the NF1 data were collected from patients of the clinic only, who may not be an accurate representation of all individuals with NF1. Such a backdrop confines certain aspects of the reported data to the particular clinic environment, which might render our statistics less optimal for generalizability to all adult NF1 populations in Canada. Furthermore, a control population was not available for comparison of responses. However, it underpins the need to raise awareness about capturing the maximal number of NF patients within the community. We have utilized this resource to improve collaboration and more efficiently link with NF communities across Canada to facilitate the process of primary data collection from all affected individuals through a secure online platform. Second, more frequent clinics provide patients with greater flexibility to arrange and make their appointments. Lastly, many of the patientreported conditions were not ascertained; therefore, similar to other epidemiological studies, we have had potential reporting and/or recall biases in our data, perhaps affecting the patient statistics. Efforts are currently underway to minimize these biases by revising and simplifying the questionnaire design, which in its current form requires approximately 30 minutes to complete.

\section{Conclusions and Future Directions}

Through this cross-sectional assessment of the patient demographics and the dynamic critical evaluation of our clinic structure, we have learned that, in addition to neurosurgery and neurology, the incorporation of a genetics team as well as neuropyschology and social work services as integral components of the clinic are of high clinical value. Having direct involvement of neuro-oncology has been invaluable in managing benign and malignant tumours in the population. Unmasking the underrecognized immune-associated manifestations is valuable to focus our clinical care and direct future research attention to this area as well.

Though our knowledge regarding this complex disorder has significantly expanded in recent times, many challenges remain. Although several clinical trials are already underway tasked with addressing some of the most pressing clinical queries in NF1, ${ }^{68-70}$ the clinical manifestations are heterogeneous and disease prevalence is low. A concerted effort to capture all patients within the provincial and national community is necessary. Central coordination of several regional multidisciplinary clinics, each with an infrastructure that is capable of supporting high patient volumes, is critical. To aid in the collection and analysis of large volumes of data, including molecular and genetic information, initiatives involving internet-based registries are underway, and early success has been attained. ${ }^{16,71}$ Awareness and cooperation with such initiatives will be an important responsibility of NF multidisciplinary clinics.

Beyond the need for collaboration among regional centres, close partnership with patient advocacy groups is a further component that must be established and fostered. In addition to introducing patients and their families to the clinical resources available, advocacy groups allow patients to connect and serve as sources of support for one another. Unfortunately, more than $80 \%$ of the patients in the current study did not know any person with NF1 other than their own family members. Through further strengthening of our partnerships with the NFSO and ANAC, it is our goal to improve upon this statistic.

\section{DisClosures}

Alireza Mansouri, Saber Ghadakzadeh, Talha Maqbool, Carolina Barnett, Karolyn Au, Paul Kongkham, Vera Bril and Gelareh Zadeh hereby declare that they have nothing to disclose.

\section{Statement of Authorship}

$\mathrm{AM}$ and SG adapted the intake questionnaire, collected and analyzed data, and wrote the manuscript. AM and TM conducted the systematic review. AM, SG, CB, PK, VB and GZ conceived of and designed the study. All authors were involved with critically editing and finalizing the text, figures and tables. In addition, all authors approved the final version of the manuscript.

\section{SupPlementary Material}

To view the supplementary material (Appendix I) for this article, please visit http://dx.doi.org/10.1017/cjn.2016.326.

\section{REFERENCES}

1. Ferner RE, Huson SM, Thomas N, Moss C, Willshaw H, Evans DG, et al. Guidelines for the diagnosis and management of individuals with neurofibromatosis 1. J Med Genet. 2007;44(2):81-8. Epub ahead of print Nov 14, 2006. Available at: http://www.ncbi.nlm. nih.gov/pmc/articles/PMC2598063/.

2. Williams VC, Lucas J, Babcock MA, Gutmann DH, Korf B, Maria BL. Neurofibromatosis type 1 revisited. Pediatrics. 2009;123(1):124-33.

3. Friedman JM. Neurofibromatosis 1. In: Pagon RA, Adam MP, Ardinger $\mathrm{HH}$, et al., editors. GeneReviews ${ }^{\circledR}$. Seattle: University of Washington; 1993-2016. Available at: http://www.ncbi.nlm. nih.gov/books/NBK1109/.

4. Neurofibromatosis Conference statement. National Institutes of Health Consensus Development Conference. Arch Neurol. 1988; 45(5):575-8.

5. Lu-Emerson C, Plotkin SR. The neurofibromatoses, part 1: NF1. Rev Neurol Dis. 2009;6(2):E47-53.

6. Delis KT, Gloviczki P. Neurofibromatosis type 1: from presentation and diagnosis to vascular and endovascular therapy. Perspect Vasc Surg Endovasc Ther. 2006;18(3):226-37.

7. McKeever K, Shepherd CW, Crawford H, Morrison PJ. An epidemiological, clinical and genetic survey of neurofibromatosis type 1 in children under sixteen years of age. Ulster Med J. 2008; 77(3):160-3. Available at: http://www.ncbi.nlm.nih.gov/pmc/ articles/PMC2604471/.

8. Rosenfeld A, Listernick R, Charrow J, Goldman S. Neurofibromatosis type 1 and high-grade tumors of the central nervous system. Childs Nerv Syst. 2010;26(6):663-7. Epub ahead of print Nov 25, 2009.

9. Van Lierde A, Menni F, Bedeschi MF, Natacci F, Guez S, Vizziello $\mathrm{P}$, Costantino MA, et al. Healthcare transition in patients with rare genetic disorders with and without developmental disability: neurofibromatosis 1 and Williams-Beuren syndrome. Am J Med Genet A. 2013;161A(7):1666-74. Epub ahead of print May 21.

10. Oates EC, Payne JM, Foster SL, Clarke NF, North KN. Young Australian adults with NF1 have poor access to health care, high complication rates, and limited disease knowledge. Am J Med Genet A. 2013;161A(4):659-66. Epub ahead of print Feb 20.

11. Wolkenstein P, Zeller J, Revuz J, Ecosse E, Leplege A. Quality-oflife impairment in neurofibromatosis type 1: a cross-sectional study of 128 cases. Arch Dermatol. 2001;137(11):1421-5.

12. Granstrom S, Langenbruch A, Augustin M, Mautner VF. Psychological burden in adult neurofibromatosis type 1 patients: impact of disease visibility on body image. Dermatology. 2012;224(2): 160-7. Epub ahead of print Apr 12. 
13. Vranceanu AM, Merker VL, Park E, Plotkin SR. Quality of life among adult patients with neurofibromatosis 1 , neurofibromatosis 2 and schwannomatosis: a systematic review of the literature. J Neurooncol. 2013;114(2):257-62. Epub ahead of print Jul 2.

14. Orion E, Feldman B, Ronni W, Orit BA. A psychodermatology clinic: the concept, the format, and our observations from Israel. Am J Clin Dermatol. 2012;13(2):97-101.

15. Duong TA, Sbidian E, Valeyrie-Allanore L, Vialette C, Ferkal S, Hadj-Rabia S, et al. Mortality associated with neurofibromatosis 1: a cohort study of 1895 patients in 1980-2006 in France. Orphanet J Rare Dis. 2011;6:18. Available at: http://www.ncbi. nlm.nih.gov/pmc/articles/PMC3095535/.

16. Johnson KJ, Hussain I, Williams K, Santens R, Mueller NL, Gutmann DH. Development of an international internet-based neurofibromatosis type 1 patient registry. Contemp Clin Trials. 2013;34(2):305-11. Epub ahead of print Dec 14, 2012.

17. Landis JR, Koch GG. The measurement of observer agreement for categorical data. Biometrics. 1977;33(1):159-74.

18. Khosrotehrani K, Bastuji-Garin S, Riccardi VM, Birch P, Friedman JM, Wolkenstein P. Subcutaneous neurofibromas are associated with mortality in neurofibromatosis 1: a cohort study of 703 patients. Am J Med Genet A. 2005;132A(1):49-53.

19. Yalcin B, Tamer E, Gur G, Oztas P, Polat MU, Alli N. Neurofibromatosis 1/Noonan syndrome associated with Hashimoto's thyroiditis and vitiligo. Acta Derm Venereol. 2006;86(3):80-1.

20. Geller M, Ribeiro MG, Araujo AP, de Oliveira LJ, Nunes FP. Serum IgE levels in neurofibromatosis 1. Int J Immunogenet. 2006; 33(2):111-5.

21. Bonalumi Filho A, Geller M, Darrigo LG Jr, Mesquita Filho J, Azulay DR. Epidemiological analysis of neurofibromatosis type 1 in a reference hospital in Rio de Janeiro State [in Portuguese]. Rev Bras Med. 2010;67(5):135-9.

22. Duong TA, Bastuji-Garin S, Valeyrie-Allanore L, Sbidian E, Ferkal S, Wolkenstein P. Evolving pattern with age of cutaneous signs in neurofibromatosis type 1: a cross-sectional study of 728 patients. Dermatology. 2011;222(3):269-73. Epub ahead of print May 4.

23. Orion E, Feldman B, Ronni W, Orit BA. A psychodermatology clinic: the concept, the format, and our observations from Israel. Am J Clin Dermatol. 2012;13(2):97-101.

24. McGaughran JM, Harris DI, Donnai D, Teare D, MacLeod R, Westerbeek R, et al. A clinical study of type 1 neurofibromatosis in north west England. J Med Genet. 1999;36(3):197-203.

25. Zoller M, Rembeck B, Akesson HO, Angervall L. Life expectancy, mortality and prognostic factors in neurofibromatosis type 1: a twelve-year follow-up of an epidemiological study in Göteborg, Sweden. Acta Derm Venereol. 1995;75(2):136-40.

26. Wang DL, Smith KB, Esparza S, Leigh FA, Muzikansky A, Park ER, et al. Emotional functioning of patients with neurofibromatosis tumor suppressor syndrome. Genet Med. 2012;14(12):977-82. Epub ahead of print Aug 9.

27. Beckman E, Akbarnia BA. The Cardinal Glennon Children's Hospital Neurofibromatosis Clinic model. Neurofibromatosis. 1988; 1(3): $134-6$

28. Noble F, Kornberg AJ, Elder JE, Delatycki MB. Retrospective analysis of patients attending a neurofibromatosis type 1 clinic. J Paediatr Child Health. 2007;43(1-2):55-9.

29. North K. Neurofibromatosis type 1: review of the first 200 patients in an Australian clinic. J Child Neurol. 1993;8(4):395-402.

30. Trovó-Marqui AB, Goloni-Bertollo EM, Valerio NI, PavarinoBertelli EC, Muniz MP, Teixeira MF, et al. High frequencies of plexiform neurofibromas, mental retardation, learning difficulties, and scoliosis in Brazilian patients with neurofibromatosis type 1. Braz J Med Biol Res. 2005;38(9):1441-7. Epub ahead of print Aug 26. Available at: http://www.scielo.br/scielo.php?script= sci_arttext\&pid=S0100-879X2005000900020\&lng=en\&nrm= iso\&tlng=en.

31. Wolkenstein P, Durand-Zaleski I, Moreno JC, Zeller J, Hemery F, Revuz J. Cost evaluation of the medical management of neurofibromatosis 1: a prospective study on 201 patients. Br J Dermatol. 2000;142(6): 1166-70.

32. Hirbe AC, Gutmann DH. Neurofibromatosis type 1: a multidisciplinary approach to care. Lancet Neurol. 2014;13(8):834-43.
Available at: http://www.thelancet.com/pdfs/journals/laneur/ PIIS1474-4422(14)70063-8.pdf.

33. Friedman JM. Neurofibromatosis 1: clinical manifestations and diagnostic criteria. J Child Neurol. 2002;17(8):548-54; discussion 571-2, 646-51.

34. Messiaen LM, Callens T, Mortier G, Beysen D, Vandenbroucke I, Van Roy N, et al. Exhaustive mutation analysis of the NF1 gene allows identification of $95 \%$ of mutations and reveals a high frequency of unusual splicing defects. Hum Mutat. 2000; 15(6):541-55.

35. Radtke HB, Sebold CD, Allison C, Haidle JL, Schneider G. Neurofibromatosis type 1 in genetic counseling practice: recommendations of the National Society of Genetic Counselors. J Genet Couns. 2007;16(4):387-407. Epub ahead of print Jul 17.

36. Huson SM, Harper PS, Compston DA. Von Recklinghausen neurofibromatosis: a clinical and population study in southeast Wales. Brain. 1988;111(Pt 6):1355-81.

37. Eliason MJ. Neurofibromatosis: implications for learning and behavior. J Dev Behav Pediatr. 1986;7(3):175-9.

38. Trzcinska M, Borkowska A. Cognitive dysfunction and emotional disturbances in children with neurofibromatosis type one (Recklinghausen's disease): review of the literature [in Polish]. Psychiatr Pol. 2005;39(2):371-81.

39. Payne JM, Hyman SL, Shores EA, North KN. Assessment of executive function and attention in children with neurofibromatosis type 1: relationships between cognitive measures and real-world behavior. Child Neuropsychol. 2011;17(4):313-29.

40. Gold DR, Cohen BH. Brain tumors in neurofibromatosis. Curr Treat Options Neurol. 2003;5(3):199-206.

41. Listernick R, Charrow J, Greenwald MJ, Esterly NB. Optic gliomas in children with neurofibromatosis type 1. J Pediatr. 1989; 114(5):788-92.

42. Listernick R, Charrow J, Greenwald M, Mets M. Natural history of optic pathway tumors in children with neurofibromatosis type 1: a longitudinal study. J Pediatr. 1994;125(1):63-6.

43. Thakkar SD, Feigen U, Mautner VF. Spinal tumours in neurofibromatosis type 1: an MRI study of frequency, multiplicity and variety. Neuroradiology. 1999;41(9):625-9.

44. Tonsgard JH, Kwak SM, Short MP, Dachman AH. CT imaging in adults with neurofibromatosis-1: frequent asymptomatic plexiform lesions. Neurology. 1998;50(6):1755-60.

45. Kehrer-Sawatzki H, Kluwe L, Funsterer C, Mautner VF. Extensively high load of internal tumors determined by whole body MRI scanning in a patient with neurofibromatosis type 1 and a nonLCR-mediated 2-Mb deletion in 17q11.2. Hum Genet. 2005; 116(6):466-75. Epub ahead of print Mar 18.

46. Tonsgard JH. Clinical manifestations and management of neurofibromatosis type 1. Semin Pediatr Neurol. 2006;13(1):2-7.

47. Tucker T, Friedman JM, Friedrich RE, Wenzel R, Funsterer C, Mautner VF. Longitudinal study of neurofibromatosis 1 associated plexiform neurofibromas. J Med Genet. 2009;46(2):81-5. Epub ahead of print Oct 17, 2008.

48. Friedrich RE, Korf B, Funsterer C, Mautner VF. Growth type of plexiform neurofibromas in NF1 determined on magnetic resonance images. Anticancer Res. 2003;23(2A):949-52.

49. Mautner VF, Hartmann M, Kluwe L, Friedrich RE, Funsterer C. MRI growth patterns of plexiform neurofibromas in patients with neurofibromatosis type 1. Neuroradiology. 2006;48(3):160-5. Epub ahead of print Jan 24.

50. Ducatman BS, Scheithauer BW, Piepgras DG, Reiman HM, Ilstrup DM. Malignant peripheral nerve sheath tumors: a clinicopathologic study of 120 cases. Cancer. 1986;57(10): 2006-21.

51. Ferner RE, Gutmann DH. International consensus statement on malignant peripheral nerve sheath tumors in neurofibromatosis. Cancer Res. 2002;62(5):1573-7. Available at: http://cancerres. aacrjournals.org/content/62/5/1573.long.

52. Friedrich RE, Keiner D, Hagel C. Expression of insulin-like growthfactor-1 receptor (IGF-1R) in peripheral nerve sheath tumors in neurofibromatosis type 1. Anticancer Res. 2007;27(4A):2085-90; Available at: http://ar.iiarjournals.org/content/27/4A/2085.long.

53. Rasmussen SA, Yang Q, Friedman JM. Mortality in neurofibromatosis 1: an analysis using U.S. death certificates. Am J Hum 
Genet. 2001;68(5):1110-8. Available at: https://www.ncbi.nlm. nih.gov/pmc/articles/PMC1226092/.

54. Park SJ, Sawitzki B, Kluwe L, Mautner VF, Holtkamp N, Kurtz A. Serum biomarkers for neurofibromatosis type 1 and early detection of malignant peripheral nerve-sheath tumors. BMC Med. 2013;11:109. Available at: https://www.ncbi.nlm.nih.gov/pmc/ articles/PMC3648455/.

55. To T, Stanojevic S, Feldman R, Moineddin R, Atenafu EG, Guan J, et al. Is asthma a vanishing disease? A study to forecast the burden of asthma in 2022. BMC Public Health. 2013;13:254. Available at: https://www.ncbi.nlm.nih.gov/pmc/articles/PMC3626860/.

56. Koga M, Koga K, Nakayama J, Imafuku S. Anthropometric characteristics and comorbidities in Japanese patients with neurofibromatosis type 1: a single institutional case-control study. J Dermatol. 2014;41(10):885-9. Epub ahead of print Sep 9.

57. Geller M, Ribeiro MG, Araujo APQC, Higino KS, Varella RB, Oliveira LB, et al. 970. p53 expression and serum IgE levels in patients with neurofibromatosis type 1. Mol Ther. 2005;11:S375. Available at: http://www.nature.com/mt/journal/v11/n1s/pdf/mt20051090a.pdf.

58. Jett K, Friedman JM. Clinical and genetic aspects of neurofibromatosis 1. Genet Med. 2010;12(11):1-11.

59. Isaacson P. Mast cells in benign nerve sheath tumours. J Pathol. 1976;119(4):193-6.

60. Cawley EP, Hoch-Ligeti C. Association of tissue mast cells and skin tumors. Arch Dermatol. 1961;83:92-6.

61. Riccardi VM. Cutaneous manifestation of neurofibromatosis: cellular interaction, pigmentation, and mast cells. Birth Defects Orig Artic Ser. 1981;17(2):129-45.

62. Baratelli F, Le M, Gershman GB, French SW. Do mast cells play a pathogenetic role in neurofibromatosis type 1 and ulcerative colitis? Exp Mol Pathol. 2014;96(2):230-4. Epub ahead of print Feb 26.
63. Ryan JJ, Klein KA, Neuberger TJ, Leftwich JA, Westin EH, Kauma $\mathrm{S}$, et al. Role for the stem cell factor/KIT complex in Schwann cell neoplasia and mast cell proliferation associated with neurofibromatosis. J Neurosci Res. 1994;37(3):415-32.

64. Trovó-Marqui AB, Tajara EH. Neurofibromin: a general outlook. Clin Genet. 2006:(1): 70:1-13. Available at: http://onlinelibrary. wiley.com/wol1/doi/10.1111/j.1399-0004.2006.00639.x/full.

65. Hiatt K, Ingram DA, Huddleston H, Spandau DF, Kapur R, Clapp DW. Loss of the NF1 tumor suppressor gene decreases Fas antigen expression in myeloid cells. Am J Pathol. 2004;164(4): 1471-9. Available at: https://www.ncbi.nlm.nih.gov/pmc/articles/ PMC1615352/.

66. Claman HN. New hope for neurofibromatosis? The mast cell connection. JAMA. 1987;258(6):823.

67. Riccardi VM. Mast-cell stabilization to decrease neurofibroma growth: preliminary experience with ketotifen. Arch Dermatol. 1987;123(8):1011-6.

68. Nantes University Hospital. Neuropsychological Impairment and Quality of Life in Neurofibromatosis Type 1 (NF1-QDV); 2016. Available at: https://clinicaltrials.gov/ct2/show/NCT01851135.

69. University of Alabama at Birmingham. A Randomized PlaceboControlled Study of Lovastatin in Children With Neurofibromatosis Type 1 (STARS); 2016. Available at: https:// clinicaltrials.gov/ct2/show/NCT00853580.

70. University of Alabama at Birmingham. A Phase II Study of the mTOR Inhibitor Sirolimus in Neurofibromatosis Type 1-Related Plexiform Neurofibromas (Protocol 102); 2016. Available at: https://clinicaltrials.gov/ct2/show/NCT00634270.

71. Johnson KJ, Mueller NL, Williams K, Gutmann DH. Evaluation of participant recruitment methods to a rare disease online registry. Am J Med Genet A. 2014;164A(7):1686-94. Epub ahead of print Apr 3. 